\title{
Susceptibility of soybean looper to lufenuron and spinosad
}

\section{Susceptibilidade da lagarta falsa-medideira a lufenuron e espinosade}

\author{
Lucas Ferraz de Queiroz' ${ }^{1}$ (D) (orcid.org/0000-0002-8755-5775) \\ Janaina De Nadai Corassa' (D) (orcid.org/0000-0002-1013-5414) \\ Sandra Maria Morais Rodrigues ${ }^{2}$ (D) (orcid.org/0000-0001-9043-4694) \\ Rafael Major Pitta ${ }^{3 *}$ (D) (orcid.org/0000-0002-8503-7106)
}

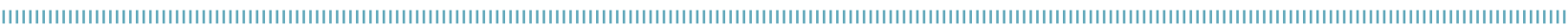

\begin{abstract}
The soybean looper (Chrysodeixis includens) is an important defoliation pest in crops such as soybean and cotton in Brazil. Its main control tactic is chemical insecticides. Considering the importance of chemical control for this pest, monitoring the susceptibility of $C$. includens populations is strategic for an efficient Insect Resistance Management. Therefore, the objective of this study was to evaluate the susceptibility levels of $C$. includens populations in the state of Mato Grosso - Brazil to lufenuron and spinosad. Seven populations were collected in soybean fields around the state. For the bioassays, early L3 larvae were exposed to insecticides using the diet-overlay method. Although the compounds have distinct modes of action, Tangará da Serra population had the highest resistance ratios for lufenuron (11.62) and spinosad (7.84), compared to laboratory population (susceptibility reference). Even with low resistance levels, it is necessary to maintain regional monitoring of $C$. includens susceptibility to the evaluated insecticides, as well as to extend the range of molecules monitored.
\end{abstract}

KEYWORDS: spinosyns; inhibitors of chitin synthesis; resistance management.
RESUMO: A lagarta falsa-medideira (Chrysodeixis includens) é uma importante praga desfolhadora em culturas como soja e algodáo no Brasil e seu principal método de controle é o uso de inseticidas químicos. Considerando a importância do controle químico para essa praga, o monitoramento da suscetibilidade de populaçôes de $C$. includens é estratégico para um eficiente programa de Manejo da Resistência de Insetos. Portanto, objetivou-se com este estudo avaliar os níveis de suscetibilidade de populaçóes de C. includens no estado de Mato Grosso, Brasil, aos inseticidas lufenurom e espinosade. Sete populaçóes foram coletadas em cultivos de soja ao longo do estado. Para os bioensaios, lagartas em terceiro ínstar foram expostas aos inseticidas utilizando o método de contaminação superficial de dieta. Embora os compostos apresentem modos de ação distintos, a população de Tangará da Serra obteve as maiores razóes de resistência para lufenurom $(11,62)$ e espinosade $(7,84)$ em relação à população de laboratório (referência de suscetibilidade). Apesar dos níveis de resistência terem sido baixos, é necessário manter a manutenção do monitoramento dos níveis de suscetibilidade aos inseticidas avaliados, assim como ampliar a gama de moléculas monitoradas.

PALAVRAS-CHAVE: espinosina; inibidores da síntese de quitina; manejo da resistência. 


\section{INTRODUCTION}

The soybean looper, Chrysodeixis includens (Walker, 1858), is an important defoliation pest because of its potential to damage crops such as soybean, cotton, beans and sunflower (SPECHT et al., 2015). These crops make up most of the productive systems in the state of Mato Grosso, Brazil (ANDRADE et al., 2016; PITTA; CROSARIOL NETTO, 2016). Therefore, C. includens is benefited pest by these productive systems, since the large host availability which enables the species to remain throughout the year at the same agroecosystem, intensifying the selection pressure of insecticides (MINK; BOETHEL, 1992).

As with most pests, its main control method is chemicals in soybean and cotton cultivars that do not express Bt proteins, and because of its intensive use the reduced efficacy of insecticides has become increasingly worrying (BERNARDI et al., 2012).

The rotation of insecticides with distinct modes of action (MoA) is an important tool in managing resistance. For this, monitoring susceptibility levels of populations is fundamental because it allows agronomists and growers to decide which compounds should compose the rotation of active ingredients in each region (ONSTAD, 2007). In Brazil, despite the economic importance of this pest, there are few studies about the susceptibility levels of $C$. includens to insecticides (SOSA-GÓMEZ; OMOTO, 2012; MURARO et al., 2019; STACKE et al., 2019).

Lufenuron belongs to the group of chitin synthesis inhibitor and acts by ingestion as a growth regulator of insects (SUN et al., 2015). In the state of Mato Grosso, the use of growth regulating insecticides, such as lufenuron, is common for controlling caterpillars in soybean crops. Preventive sprays with this chemical group to control caterpillars are frequent and usually associated to some necessary spraying of herbicide or fungicide. Therefore, there is a potential risk of selecting resistant populations of $C$. includens to the lufenuron molecule due to its intense selection pressure.
Compounds with low selection pressure are important for good compound rotation. In this sense, it is believed that spinosyns are strategic compounds, because their use in soybean is much reduced for lepidoptera control when compared to lufenuron. Spinosad belongs to the group of spinosyns that act as allosteric activators of nicotinic acetylcholine receptors, in addition to acting on gamma-aminobutyric acid receptors — GABA (IRAC, 2016; SCOTT, 2008). Considering that spinosad has a distinct action mechanism from lufenuron and its use is lower, it is assumed that this molecule is a good alternative for managing the resistance of $C$. includens to growth regulating insecticides such as lufenuron.

Considering that the area planted with soybean in the state is approximately 9 million hectares (CONAB, 2018), there must be significant variations in susceptibility levels among C. includens populations to insecticidal molecules. Therefore, our objective with this study was to evaluate the susceptibility levels of $C$. includens populations to the spinosad and lufenuron compounds in Mato Grosso.

\section{MATERIAL AND METHODS}

\section{Insect collection of Crysodeixis includens and rearing procedure}

A susceptible reference population (denominated SUS) was obtained from Embrapa Soja, Londrina, Paraná, and kept in the laboratory for more than three years free from the selection pressure of insecticides. The $C$. includens field populations were collected in georeferenced soybean production areas in the state of Mato Grosso, Brazil, during the 2015/2016 crop season (Table 1). We collected approximately 200 individuals, with standardized instar, per field.

Table 1. Locations, sampling sites, dates, host plant, number of insects collected of Chrysodeixis includens in Mato Grosso.

\begin{tabular}{|c|c|c|c|c|}
\hline Locations & Sites & Collection date & Crop & Insects collected (n) \\
\hline Claudia & $\begin{array}{l}11^{\circ} 14^{\prime} 58.85^{\prime \prime} \mathrm{S} \\
54^{\circ} 58^{\prime} 18.98^{\prime \prime} \mathrm{W}\end{array}$ & $\mathrm{Dec} / 2015$ & soybean & 154 \\
\hline Nova Mutum & $\begin{array}{l}13^{\circ} 54^{\prime} 44.46^{\prime \prime} \mathrm{S} \\
55^{\circ} 47^{\prime} 9.06^{\prime \prime} \mathrm{W}\end{array}$ & Jan/2016 & soybean & 210 \\
\hline Ipiranga do Norte & $\begin{array}{c}12^{\circ} 5^{\prime} 18.69^{\prime \prime} \mathrm{S} \\
55^{\circ} 58^{\prime} 25.57 \text { 'W }\end{array}$ & Jan/2016 & soybean & 180 \\
\hline Diamantino & $\begin{array}{l}14^{\circ} 24^{\prime} 39.83^{\prime \prime} \mathrm{S} \\
56^{\circ} 31^{\prime} 39.61^{\prime \prime} \mathrm{W}\end{array}$ & Feb/2016 & soybean & 220 \\
\hline Tangará da Serra & $\begin{array}{l}14^{\circ} 38^{\prime} 6.77^{\prime \prime} \mathrm{S} \\
57^{\circ} 34^{\prime} 9.45^{\prime \prime} \mathrm{O}\end{array}$ & $\mathrm{Feb} / 2016$ & soybean & 150 \\
\hline Sorriso & $\begin{array}{c}12^{\circ} 32^{\prime} 2.09^{\prime \prime} \mathrm{S} \\
55^{\circ} 54^{\prime} 16.06^{\prime \prime} \mathrm{W}\end{array}$ & Jan/2016 & soybean & 167 \\
\hline União do Sul & $\begin{array}{l}11^{\circ} 29^{\prime} 13.48^{\prime \prime} \mathrm{S} \\
54^{\circ} 7^{\prime} 34.34^{\prime \prime} \mathrm{W}\end{array}$ & $\mathrm{Dec} / 2015$ & soybean & 240 \\
\hline
\end{tabular}


They were conditioned on plastic plates with six cells $(35 \times$ $17.5 \times 20 \mathrm{~mm}$ ) filled with $3 \mathrm{~mL}$ of artificial diet (PARRA, 1999 ) and kept in styrofoam boxes. Upon arriving at the laboratory, the caterpillars were transferred to glass tubes $(2.5 \times 8.5 \mathrm{~cm})$ containing $10 \mathrm{~mL}$ of artificial diet. After the emergence of adults, about 20 couples were transferred to each PVC tube cage $(20 \mathrm{~cm}$ in diameter by $30 \mathrm{~cm}$ in height) internally covered with sulphite paper.

For adult feeding, plastic cups were used with cotton soaked in $10 \%$ honey solution inside the cages. The adults were kept in a breeding room at $26 \pm 2^{\circ} \mathrm{C}$, relative humidity of $70 \pm 5 \%$ and photophase of 14 hours. The paper coating of the cages and plastic cups containing food for the adults were changed every two days.

The eggs laid on the paper were cut and packed in transparent acrylic gerbox boxes $(11 \times 11 \times 4 \mathrm{~cm})$ with diet and kept in an incubator chamber with a temperature set at $25 \pm 1{ }^{\circ} \mathrm{C}$, relative humidity of $70 \pm 5 \%$ and photophase of 14 hours until the caterpillars hatched. Newborn caterpillars were divided into two lots for each population; one for bioassays with third instar and another for population maintenance.

\section{Insecticides}

Match ${ }^{\circledast}$ CE lot: PLN 3 E L (50 g.L L $^{-1}$ lufenuron, Syngenta crop protection, Sáo Paulo City, Sáo Paulo State) and Tracer $^{\oplus}$ SC lot: 025-14-3000 (480 g.L $\mathrm{L}^{-1}$ spinosad, Dow AgroSciences Industrial Ltda., São Paulo, SP) insecticides were used.

\section{Bioassay}

A superficial treatment method of an artificial diet with insecticide was implemented (MASCARENHAS; BOETHEL, $2000)$ in each cell of the plastic plate (Costar ${ }^{\circledR}$, Cambridge, Massachusetts, USA), with 24 cells containing $1.5 \mathrm{~mL}$ of artificial diet and submitted to ultraviolet light. The insecticides were diluted in purified water with the addition of $0.1 \%(\mathrm{v} / \mathrm{v})$ of Break-thru ${ }^{\circledast}$ to obtain uniform spread solutions over the diet surfaces. About six to seven concentrations with at least five plastic plates were made in each bioassay.

Twenty $\mu \mathrm{L}$ of the insecticidal solution was transferred to each cell of the plate using a multipette ${ }^{\circledast} \mathrm{M} 4$ dispenser. The control treatment plates received $0.1 \%(\mathrm{v} / \mathrm{v})$ adhesive spreader only.

After contaminating the diet's surface with insecticide, the plates were kept in a laminar flow chamber for at least two hours until the insecticide solution was dried. Third instar caterpillars were subsequently individualized in the cells with the aid of a fine brush. The plates were kept in climatic chambers with a temperature of $25 \pm 2^{\circ} \mathrm{C}$, relative humidity of 70 $\pm 10 \%$ and photophase of 14 hours.

\section{Determination of the bioassay evaluation time}

Mortalities were evaluated at 24, 48, 72 and 96 hours after installing the spinosad, and 24, 48, 72, 96 and 120 hours for lufenuron to determine the mortality times that provided results with lower variations for the two compounds. The determination of the best time to evaluate the mortality of $C$. includens was done by obtaining the largest slope and the lower $\mathrm{LC}_{50}$ confidence threshold (TWINE; REYNOLDS, 1980). Individuals were considered dead when they were touched with the tip of a brush in the last abdominal segments and did not respond with coordinated movements.

In order to determine the evaluation time, the susceptible reference populations were submitted to logarithmically spaced concentrations [ $\mu \mathrm{g}$ A.I. $\mathrm{mL}^{-1}$ ] obtained from diluting the insecticides in water, which resulted in mortalities between 5 and $99 \%$. The bioassays were performed as previously described.

\section{Statistical analysis}

Mortality data were corrected by the control mortality using the Abbott formula (ABBOTT, 1925) and analyzed by Probit (FINNEY, 1971) using the Priprobit program (v. 1.63). The mean lethal concentration values $\left(\mathrm{LC}_{50}\right.$ and $\left.\mathrm{LC}_{95}\right)$ were estimated with their confidence intervals $(95 \% \mathrm{CI})$ and the curve slopes with their standard errors (SE) (BLISS, 1934; SAKUMA, 1998), being considered significantly different when their respective $95 \%$ confidence limits (CLs), and standard errors did not overlap. The resistance ratios (RR) of the C. includens field populations were obtained from the division of their $\mathrm{LCs}_{50}$ by the $\mathrm{LC}_{50}$ of the susceptible reference population (SUS).

\section{RESULTS}

\section{Determination of the evaluation time}

Seven hundred and sixty-eight caterpillars were used in the lufenuron trial, and mortality was assessed every 24 hours up to 120 hours (Table 2). In the evaluations of 24, 48 and 72 hours, the $\mathrm{LC}_{50}$ and $\mathrm{LC}_{95}$ had the lowest slopes and the highest $95 \%$ confidence intervals; therefore, being inadequate to evaluate the mortality of caterpillars to lufenuron. The evaluation periods of 96 and 120 hours obtained the highest slopes (5.8 \pm 0.51 and $5.8 \pm 0.62$, respectively); however, the standard error of 96 hours was lower, and it was then used for the mortality evaluations of the other populations.

Seven hundred and seventy-four caterpillars were used for the spinosad test, and mortality was assessed every 24 hours until 96 hours (Table 3). Though the 24-hour evaluation 
showed the highest slope $(2.44 \pm 0.24)$, its $\mathrm{LC}_{50}$ confidence interval was high $[5,874.77(1,885.11-58,372.70)]$ in comparison with the other periods, as well as in the evaluation at 48 hours [666.18 (377.53 - 1,690.99)]. The slope of 72 and 96 hours were the same when the standard error was considered $(2.07 \pm 0.25$ and $2.15 \pm 0.38$, respectively), but the $\mathrm{LC}_{50}$ confidence interval at 72 hours $[17.22(13.89-20.67)$ was shorter than at 96 hours $[14.69(8.79-20.95)]$. Thus, the 72-hour mortality assessment for the spinosad molecule was defined.

\section{Status of $\boldsymbol{C}$. includens susceptibility to lufenuron and spinosad}

\section{Lufenuron}

The populations of Nova Mutum and Ipiranga do Norte and obtained the lowest $\mathrm{CLs}_{50}[1.04(0.87-1.77)$ and 1.24 $(1.1-1.47)$, respectively], being grouped with the susceptible population $[0.94(0.82-1.06)]$ when considering the confidence intervals. Tangará da Serra's population had the highest $\mathrm{LC}_{50}\left[10.92(8.78-12.99] \mu \mathrm{g}\right.$ A.I. $\mathrm{mL}^{-1}$, followed by Diamantino's [4.97 (3.85 - 6.14] $\mu$ g A.I. $\mathrm{mL}^{-1}$, obtaining the resistance ratios of 11.62 and $9.98 x$, respectively (Table 4).

\section{Spinosad}

For spinosad, none of the populations grouped with the susceptible population (Table 5) when assessing the confidence intervals of $\mathrm{LCs}_{50}$. The populations of Claudia $\left[\mathrm{LC}_{50}\right.$ $=37.81(31.43-77.47)]$, Ipiranga $\left[\mathrm{LC}_{50}=51.37\right.$ (35.1173.14)], Nova Mutum LC $\left._{50}=51.66(43.06-61.74)\right]$ and União do Sul $\left[\mathrm{LC}_{50}=58.75\right.$ (46.73 - 71.99) $]$ did not differ from each other when considering their confidence intervals. The populations of Diamantino $\left[\mathrm{LC}_{50}=89.45(67.77\right.$ $-112.53)]$ and Sorriso $\left[\mathrm{LC}_{50}=87.53(75.5-100.75)\right]$ had an intermediate level of susceptibility, whereas Tangara da Serra's obtained the highest $\mathrm{LC}_{50}$ [134.98 (113.7 - 159.35)], with the highest resistance ratios obtained in the populations of Tangará da Serra (7.84), Diamantino (5.19) and Sorriso (5.08).

Table 2. Evaluation of mortality-time of $C$. includens (SUS) to lufenuron.

\begin{tabular}{|c|c|c|c|c|c|}
\hline Time (h) & $\mathbf{n}^{\mathrm{a}}$ & Slope $\pm(\mathrm{SE})^{\mathrm{b}}$ & 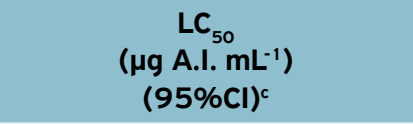 & $\begin{array}{c}\text { LC }_{95} \\
\left(\mu \mathrm{g} \mathrm{A.I.} \mathrm{mL}^{-1}\right) \\
(95 \% \mathrm{Cl})^{d}\end{array}$ & $\chi^{2 e}$ \\
\hline 24 & 768 & $0.951 \pm 0.249$ & $369.19(95.33-21259.69)$ & $19871.77(1376.72-73737597.14)$ & 3.03 \\
\hline 48 & 768 & $0.738 \pm 0.155$ & $192.09(65.70-2182.94)$ & $\begin{array}{c}32536.31 \\
(2649.10-12482120)\end{array}$ & 1.82 \\
\hline 72 & 768 & $1.42 \pm 0.12$ & $\begin{array}{c}5.06 \\
(2.46-12.59)\end{array}$ & $\begin{array}{c}73.39 \\
(22.87-3309.36)\end{array}$ & 33.30 \\
\hline 96 & 768 & $2.17 \pm 0.19$ & $\begin{array}{c}0.94 \\
(0.82-1.06)\end{array}$ & $5.37(4.29-7.15)$ & 1,96 \\
\hline 120 & 768 & $2.21 \pm 0.23)$ & $\begin{array}{c}0.86 \\
(0.75-0.98)\end{array}$ & $4.79(3.63-7.01)$ & 1,01 \\
\hline
\end{tabular}

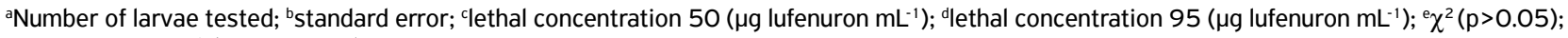
95\% Cl: 95\% confidence interval.

Table 3. Evaluation of mortality-time of $C$. includens (SUS) to spinosad.

\begin{tabular}{|c|c|c|c|c|c|}
\hline Time (h) & $\mathrm{n}^{\mathrm{a}}$ & $\begin{array}{l}\text { Slope } \\
\pm(S E)^{b}\end{array}$ & $\begin{array}{c}\text { LC }_{50} \\
\left(\mu \mathrm{g} \mathrm{A.I.} \mathrm{mL}^{-1}\right) \\
(95 \% \mathrm{Cl})^{\mathrm{c}}\end{array}$ & $\begin{array}{c}\text { LC }_{95} \\
\left(\mu \mathrm{g} \mathrm{A.I.} \mathrm{mL}^{-1}\right) \\
(95 \% \mathrm{Cl})^{d}\end{array}$ & $\begin{array}{c}\chi^{2} \\
(\mathrm{df})^{e}\end{array}$ \\
\hline 24 & 774 & $\begin{array}{c}2.43 \\
(0.24)\end{array}$ & $\begin{array}{c}5.874 .77 \\
(1,885.11-58,372,7)\end{array}$ & $\begin{array}{c}2,050.495 \\
(149,140-473,109.541)\end{array}$ & $\begin{array}{c}6.64 \\
(5)\end{array}$ \\
\hline 48 & 774 & $\begin{array}{c}1.91 \\
(0.20)\end{array}$ & $\begin{array}{c}666.18 \\
(377.53-1,690.99)\end{array}$ & $\begin{array}{c}177,769 \\
(31,748.9-3,759.250)\end{array}$ & $\begin{array}{l}1.35 \\
(5)\end{array}$ \\
\hline 72 & 774 & $\begin{array}{c}2.07 \\
(0.25)\end{array}$ & $\begin{array}{c}17,22 \\
(13.89-20.67)\end{array}$ & $\begin{array}{c}164.34 \\
(115.55-273.34)\end{array}$ & $\begin{array}{l}1.35 \\
(5)\end{array}$ \\
\hline 96 & 774 & $\begin{array}{c}2.15 \\
(0.38)\end{array}$ & $\begin{array}{c}14.69 \\
(8.79-20.95)\end{array}$ & $\begin{array}{c}114.13 \\
(69.73-284.36)\end{array}$ & $\begin{array}{l}13.04 \\
(5)\end{array}$ \\
\hline
\end{tabular}

aNumber of larvae tested; bstandard error; clethal concentration 50 ( $\mu \mathrm{g}$ spinosad $\mathrm{mL}^{-1}$ ); dethal concentration 95 ( $\mu \mathrm{g}$ spinosad $\left.\mathrm{mL}^{-1}\right)$; ${ }^{\mathrm{e}} \chi^{2}(\mathrm{p}>0.05$ ); df: degrees of freedom; $95 \% \mathrm{Cl}$ : $95 \%$ confidence interval. 


\section{DISCUSSION}

Lufenuron and other insect growth regulators have been widely used in lepidopteran control in Brazil, which justify a constant monitoring program to keep their control in field satisfactory. In contrast to our study, large resistance ratios in C. includens populations in the state of Mato Grosso were detected for novaluron and teflubenzuron (STACKE et al., 2019). Considering both compounds are inhibitors of chitin biosynthesis as well as lufenuron, there is a possibility of cross-resistance.
Another study with lepidopteran, Plutella xylostella, reports populations of this pest with high resistance ratios: up to 700-fold resistance (SANTOS et al., 2011). However, reestablishment of susceptibility is possible whether the inheritance pattern of resistance be recessive or incompletely recessive as demonstrated in a study with Spodoptera frugiperda resistant to lufenuron (NASCIMENTO et al., 2016). Therefore, the knowledge of genetic basis of chitin systhesis inhibitors to $C$. includens becomes strategic for designing an efficient management plan of the resistance of this pest to insecticides.

Table 4. Susceptibility of $C$. includens populations to lufenuron.

\begin{tabular}{|c|c|c|c|c|c|c|c|}
\hline Colonies & $n^{a}$ & $F^{b}$ & $\begin{array}{c}\chi^{2} \\
(\mathrm{df})^{c}\end{array}$ & $\begin{array}{l}\text { Slope } \\
\pm(S E)^{d}\end{array}$ & $\begin{array}{c}\text { LC }_{50} \\
(95 \% \mathrm{Cl})^{e}\end{array}$ & $\begin{array}{c}\text { LC }_{95} \\
(95 \% \mathrm{Cl})^{f}\end{array}$ & $\mathbf{R R}^{\mathbf{g}}$ \\
\hline Sus & 768 & - & $\begin{array}{l}1.96 \\
(4)\end{array}$ & $2.17(0.19)$ & $\begin{array}{c}0.94 \\
(0.82-1.06)\end{array}$ & $\begin{array}{c}5.37 \\
(4.29-7.15)\end{array}$ & 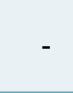 \\
\hline Nova Mutum & 768 & 3 & $\begin{array}{l}8.7 \\
(5)\end{array}$ & $5.17(0.42)$ & $\begin{array}{c}1.04 \\
(0.87-1.77)\end{array}$ & $\begin{array}{c}7.62 \\
(5.85-10.71)\end{array}$ & 1.11 \\
\hline Ipiranga do Norte & 768 & 3 & $\begin{array}{l}3.6 \\
(5)\end{array}$ & $4.34(0.34)$ & $\begin{array}{c}1.24 \\
(1.01-1.47)\end{array}$ & $\begin{array}{c}14.26 \\
(10.49-21.13)\end{array}$ & 1.33 \\
\hline União Do Sul & 767 & 3 & $\begin{array}{l}10.9 \\
(5)\end{array}$ & $4.41(0.33)$ & $\begin{array}{c}1.49 \\
(1.24-1.77)\end{array}$ & $\begin{array}{c}17.51 \\
(12.85-25.97)\end{array}$ & 1.59 \\
\hline Diamantino & 864 & 3 & $\begin{array}{c}10.82 \\
(5)\end{array}$ & $5.40(0.42)$ & $\begin{array}{c}4.97 \\
(3.85-6.14)\end{array}$ & $\begin{array}{c}53.66 \\
(39.89-79.52)\end{array}$ & 9.98 \\
\hline Tangará da Serra & 767 & 7 & $\begin{array}{l}9.04 \\
(5)\end{array}$ & $7.57(0.68)$ & $\begin{array}{c}10.92 \\
(8.78-12.99)\end{array}$ & $\begin{array}{c}70.77 \\
(53.25-107.32)\end{array}$ & 11.6 \\
\hline
\end{tabular}

aNumber of larvae tested; bnumber of the generation tested; ${ }^{c} \chi^{2}(p>0.05)$; dstandard error; elethal concentration 50 ( $\mu \mathrm{g}$ lufenuron $\left.\mathrm{mL}^{-1}\right)$; ${ }^{\mathrm{f}}$ lethal concentration 95 ( $\mu$ g lufenuron $\mathrm{mL}^{-1}$ ); ${ }^{9}$ resistance ratio (RR): LC5O of the field-collected population/LC5O of the Lab-sus strain; df: degrees of freedom; $95 \% \mathrm{Cl}$ : $95 \%$ confidence interval.

Table 5. Susceptibility of $C$. includens populations to spinosad.

\begin{tabular}{|c|c|c|c|c|c|c|c|}
\hline Colonies & $n^{a}$ & $F^{b}$ & $\begin{array}{c}\chi^{2} \\
(\mathbf{d f})^{c}\end{array}$ & $\begin{array}{l}\text { Slope } \\
\pm(S E)^{d}\end{array}$ & $\begin{array}{c}\mathrm{LC}_{50} \\
(95 \% \mathrm{Cl})^{e}\end{array}$ & $\begin{array}{c}L_{95} \\
(95 \% \mathrm{Cl})^{f}\end{array}$ & $\mathbf{R R}^{\mathrm{g}}$ \\
\hline Sus & 774 & - & $\begin{array}{l}1.35 \\
(4)\end{array}$ & $\begin{array}{c}2.07 \\
(0.25)\end{array}$ & $\begin{array}{c}17.22 \\
(13.89-20.67)\end{array}$ & $\begin{array}{c}164.34 \\
(115.55-273.34)\end{array}$ & - \\
\hline Claudia & 746 & 2 & $\begin{array}{l}9.46 \\
(5)\end{array}$ & $3.03(0.3)$ & $\begin{array}{c}37.81 \\
(31.43-77.47)\end{array}$ & $\begin{array}{c}271.23 \\
(207.3-388.73)\end{array}$ & 2.20 \\
\hline Ipiranga & 676 & 2 & $\begin{array}{l}9.70 \\
(5)\end{array}$ & $\begin{array}{c}3.22 \\
(0.45)\end{array}$ & $\begin{array}{c}51.37 \\
(35.11-73.14)\end{array}$ & $\begin{array}{c}381.33 \\
(213.32-1,207.66)\end{array}$ & 2.98 \\
\hline Nova Mutum & 710 & 2 & $\begin{array}{l}4.86 \\
(5)\end{array}$ & $\begin{array}{c}2.62 \\
(0.26)\end{array}$ & $\begin{array}{c}51.66 \\
(43.06-61.74)\end{array}$ & $\begin{array}{c}613.53 \\
(411.81-1,068.54)\end{array}$ & 3.00 \\
\hline União do Sul & 530 & 2 & $\begin{array}{l}2.75 \\
(5)\end{array}$ & $\begin{array}{c}2.70 \\
(0.30)\end{array}$ & $\begin{array}{c}58.75 \\
(46.73-71.99)\end{array}$ & $\begin{array}{c}699.3 \\
(471.39-1,225.78)\end{array}$ & 3.41 \\
\hline Sorriso & 672 & 2 & $\begin{array}{l}2.86 \\
(5)\end{array}$ & $\begin{array}{c}4.20 \\
(0.37)\end{array}$ & $\begin{array}{c}87.53 \\
(75.5-100.75)\end{array}$ & $\begin{array}{c}502.41 \\
(388.37-706.84)\end{array}$ & 5.08 \\
\hline Diamantino & 420 & 2 & $\begin{array}{l}1.55 \\
(5)\end{array}$ & $\begin{array}{c}3.09 \\
(0.38)\end{array}$ & $\begin{array}{c}89.45 \\
(67.77-112.53)\end{array}$ & $\begin{array}{c}975.17 \\
(659.16-1,731.06)\end{array}$ & 5.19 \\
\hline Tangará da Serra & 764 & 6 & $\begin{array}{l}2.56 \\
(5)\end{array}$ & $\begin{array}{c}3.46 \\
(0.29)\end{array}$ & $\begin{array}{c}134.98 \\
(113.7-159.35)\end{array}$ & $\begin{array}{c}1,388.97 \\
(998.38-2,144.46)\end{array}$ & 7.84 \\
\hline
\end{tabular}

aNumber of larvae tested; bnumber of the generation tested; ${ }^{c} \chi^{2}(p>0.05)$; ${ }^{d}$ standard error; elethal concentration 50 ( $\left.\mu \mathrm{g} \mathrm{spinosad} \mathrm{mL}^{-1}\right)$; ${ }^{\mathrm{f}}$ lethal concentration 95 ( $\mu \mathrm{g}$ spinosad $\mathrm{mL}^{-1}$ ); ${ }^{9}$ resistance ratio (RR): LC5O of the field-collected population/LC50 of the Lab-sus strain. df: degrees of freedom; 95\% Cl: 95\% confidence interval. 
For spinosad, our results show the $\mathrm{LC}_{50}$ values of the seven populations of Mato Grosso are within the range of 17.22 134.98 $\mu$ g A.I. $\mathrm{mL}^{-1}$, indicating that susceptibility remains, since the highest resistance ratio considering the $\mathrm{LC}_{50}$ among the seven C. includens populations was 7.84 times for Tangará da Serra.

Although our study did not find large resistance rations for spinosad, previous studies in Brazil for Tuta absoluta reported resistance ratios upper to 90-fold resistance (CAMPOS, 2015). In Pakistan, the resistance of spinosad to Spodoptera exigua remained very low from 1998-2008; however, this level increased, reaching in 2017 very high resistance ratios (AHMAD et al., 2018). OKUMA et al. (2018), when studying the inheritance pattern of $S$. frugiperda resistant to spinosad, concluded the resistance was incompletely recessive and polygenic. However, a possible resistance of $C$. includens to this compound will not necessarily present the same standard.

Tangará da Serra's and Diamantino's populations had the highest resistance ratios for lufenuron and spinosad, even though they are compounds with different action mechanisms. ONSTAD (2013) points out that it is common for field populations to exhibit simultaneous resistance to more than one action mode when resistance to a particular molecule is followed by rapid evolution to a second molecule used in sequence. Thus, studies with resistant individuals are required to assess whether there is multiple or cross-resistance between these two molecules (BIRD, 2016; OSORIO et al., 2008; SHAD et al., 2010).

In relation to resistance mechanisms, studies showing a resistance mechanism based on metabolites are found in the literature due to the increase in cytochrome P450 monooxygenase production in $S$. exigua and Helicoverpa armigera species to spinosad (SANG et al., 2015; SPARKS et al., 2012; WANG et al., 2006; WANG et al., 2009). DABORN et al. (2002) also observed changes in $\mathrm{P} 450$ in a lufenuron resistant strain of Drosophila melanogaster, as well as KOTZE; SALES (2001) for the dipteran Lucilia cuprina resistant to diflubenzuron.

In relation to the Tangará da Serra's population, it is possible to infer that population in field may present higher RR than those reported in this study, because the bioassays were established with the seventh generation of this population, which may decrease the resistance ratio for this population due to the absence of selection pressure. REHAN; FREED (2014) found that $S$. litura resistant to spinosad significantly reduced its $\mathrm{LC}_{50}$ generation after generations when maintained without contact with the insecticide.

Although we did not detect large resistance ratios for both insecticides, a constant monitoring is needed to detect the resistance evolution. Additionally, we believe the establishment of a regional rotation plan of active ingredients contemplating an elevated number of monitored compounds may contribute to a better efficiency in pest control, as well as a lower demand of pesticides.ha ${ }^{-1}$, promoting an agriculture with less impact on the environment.

\section{CONCLUSION}

In our study, we did not detect large resistance ratios of lufenuron and spinosad for $C$. includens populations in the state of Mato Grosso. Nonetheless, there are variabilities among the $\mathrm{LC}_{50}$ populations, which reveal that resistant populations may be selected if sequential sprays with the same compounds occur.

ACKNOWLEDGMENTS: Not applicable.

FUNDING: This study was funded by Associação dos Produtores de Soja e Milho do Estado de Mato Grosso (grant number 50.200/2017).

CONFLICTS OF INTEREST: The authors certify that they have no commercial or associative interest that represents a conflict of interest in connection with the manuscript.

ETHICAL APPROVAL: Not applicable.

AVAILABILITY OF DATA AND MATERIAL: All data generated or analyzed during this study are included in this published article AUTHORS' CONTRIBUTIONS: Conceptualization: Pitta, R.M.; Data curation and Formal analysis: Queiroz, L.F.; Methodology: Pitta, R.M.; Queiroz, L.F.; Writing - review \& editing: Pitta, R.M.; Queiroz, L.F.; Corassa, J. De N.; Rodrigues, S.M.M.

| || | | | | | | | | | | | | | | | | | | | | | | | | | | | | | | | | | | | | | | | | | | | | | | | | | | | | | | | | | | | | | | | | | | | | | | | | | | | | | | | | | | | | | | | | | | | | | | | | | | | | | | | | | | | | | | | | | | | | | | | | | | | | | | | | | | | | | | | | | | | | | | | | | | | | | | | | | | | | | | | | | | | | | | | | | | | | | | | | | | | | | | | | | | | | | | | | | | | | | | | | | | | | || || REFERENCES

ABBOTT, W.S. A method of computing the effectiveness of an insecticide. Journal of Economic Entomology, Lanham, v.18, n.2, p.265-267, 1925. https://doi.org/10.1093/ jee/18.2.265a
AHMAD, M.; ABID, F.; MUHAMMAD, S. Resistance to new insecticides and their synergism in Spodoptera exigua (Lepidoptera: Noctuidae) from Pakistan. Crop Protection, Guildford, v. 107, p.79-86, 2018. https://doi.org/10.1016/j.cropro.2017.12.028 
ANDRADE, K.; BUENO, A.D.F.; SILVA, D M.; STECCA, C.D.S.; PASINI, A.; OLIVEIRA, M.C.N. Bioecological characteristics of Chrysodeixis includens (Lepidoptera: Noctuidae) fed on different hosts. Austral Entomology, Melbourne, v.55, n.4, p.449-454, 2016. https:// doi.org/10.1111/aen.12208

BERNARDI, O.; MALVESTITI, G.S.; DOURADO, P.M.; OLIVEIRA, W.S.; MARTINELLI, S.; BERGER, G.U.; HEAD, P.G.; OMOTO, C. Assessment of the high-dose concept and level of control provided by MON $87701 \times$ MON 89788 soybean against Anticarsia gemmatalis and Pseudoplusia includens (Lepidoptera: Noctuidae) in Brazil. Pest Management Science, Sussex, v.68, n.7, p.1083-1091, 2012. https://doi.org/10.1002/ps.3271

BIRD, L.J. Genetics, cross-resistance and synergism of indoxacarb resistance in Helicoverpa armigera (Lepidoptera: Noctuidae). Pest Management Science, Sussex, v.73, n.3, p.575-581, 2016. https://doi.org/10.1002/ps.4334

BLISS, C.I. The method of probits. Science, Washington, v.79, n.2037, p.38-39, 1934. http://dx.doi.org/10.1126/ science.79.2037.38

CAMPOS, M.R.; SILVA, T.B.M.; SILVA, W.M.; SILVA, J.E.; SIQUEIRA, H.A.A. Spinisyn resistance in the tomato borer Tuta absoluta (Meirick) (Lepidoptera: Gelechiidae). Journal of Pest Science, Sussex, v.88, n.2, p.405-412, 2015. https://doi.org/10.1007/ s10340-014-0618-y

COMPANHIA NACIONAL DE ABASTECIMENTO - CONAB. Acompanhamento da safra brasileira de grãos: décimo segundo levantamento. Safra 2017/18. 5. 148p, setembro, 2018. Available from: http//conab.gov.br. Accessed on: Oct. 10 2018. https://www. conab.gov.br/info-agro/safras/graos/boletim-da-safra-de-graos/ item/9983-12-levantamento-safra-2017-18

DABORN, P.J.; YEN, J.L.; BOGWITZ, M.R.; LE GOFF, G.; FEIL, E.; JEFFERS, S.; TIJET, N.; PERRY, T.; HECKEL, D.; BATTERHAM, P.; FEYEREISEN, R.; WILSON, T.G.; FFRENCH-CONSTANT, R.H. A single $\mathrm{P} 450$ allele associated with insecticide resistance in Drosophila. Science, Washington, v.297, n.5590, p.2253-2256, 2002. https://doi.org/10.1126/science. 1074170

FINNEY, D.J. Probit Analysis. $3^{\text {rd }}$ ed. London: Cambridge University Press, 1971.333p.

INSETICIDE RESISTANCE ACTION COMMMITEE - IRAC. The IRAC e-classification: an interactive mode of action (MoA) tool. Available from: http://www.irac-online.org/modes-of-action/. Access on: Dec. 122016.

KOTZE, A.C.; SALES, N. Inheritance of diflubenzuron resistance and monooxygenase activities in a laboratory-selected strain of Lucilia cuprina (Diptera: Calliphoridae). Journal of Economic Entomology, Lanhan, v.94, n.5, p.1243-1248, 2001. https:// doi.org/10.1603/0022-0493-94.5.1243

MASCARENHAS, R.N.; BOETHEL, D.J. Development of diagnostic concentrations for insecticide resistance monitoring in soybean looper (Lepidoptera: Noctuidae) larvae using an artificial diet overlay bioassay. Journal of Economic Entomology, Lanham, v.93, n.3, p.897-904, 2000. https://doi.org/10.1093/jee/93.3.897
MINK, J.S.; BOETHEL, D.J. Development of a diagnostic technique for monitoring permethrin resistance in soybean looper (Lepidoptera: Noctuidae) larvae. Journal of Economic Entomology, Lanham, v.85, n.4,p.1056-1062, 1992. https://doi.org/10.1093/jee/85.4.1056

MURARO, D.S.; GIACOMELLI, T.; STACKE, R.F.; GODOY, D.N.; MARÇON, P.; HOLLY, P.M.; POPHAM, J.R.P.; BERNARDI, O. Baseline susceptibility of Brazilian populations of Chrysodeixis includens (Lepidoptera: Noctuidae) to $C$. includens Nucleopolyhedrovirus and diagnostic concentration for resistance monitoring. Journal of Economic Entomology, Lanhan, v. 112 , n.1, p.349-354, 2019. https://doi.org/10.1093/jee/toy361

NASCIMENTO, A.R.B.D.; FARIAS, J.R.; BERNARDI, D.; HORIKOSHI, R.J.; ОMOTO, C. Genetic basis of Spodoptera frugiperda (Lepidoptera: Noctuidae) resistance to the chitin synthesis inhibitor lufenuron. Pest Management Science, Sussex, v.72, n.4, p.810-815, 2016. https://doi.org/10.1002/ps.4057

OKUMA, D.M.; BERNARDI, D.; HORIKOSHI, R.J.; BERNARDI, O.; SILVA, A.P.; OMOTO, C. Inheritance and fitness costs of Spodoptera frugiperda (Lepidoptera: Noctuidae) resistance to spinosad in Brazil. Pest Management Science, Sussex, v.74, n.6, p.11411148, 2018. https://doi.org/10.1002/ps.4829

ONSTAD, D.W. Insect resistance management: biology, economics, and prediction. Amsterdam: Academic Press, 2007.

ONSTAD, D.W. Major issues in insect resistance management. In: ONSTAD, D.W. Insect resistance management: biology, economics and prediction. London: Elsevier, 2013. p.1-23.

OSORIO, A.; MARTÍNEZ, A.M.; SCHNEIDER, M.I.; DÍAZ, O.; CORRALES, J.L.; AVILÉS, M.C.; SMAGGHE, G.; PINEDA, S. Monitoring of beet armyworm resistance to spinosad and methoxyfenozide in Mexico. Pest Management Science, Sussex, v.64, n.10, p.1001-1007, 2008. https://doi.org/10.1002/ps. 1594

PARRA, J.R.P. Técnicas de criação de insetos para programas de controle biológico. Piracicaba: ESALQ, 1999. 138p.

PITTA, R.M.; CROSARIOL NETTO, J. Riscos e oportunidades: lagartas Heliothinae. In: ASSOCIAÇÃOMATO-GROSSENSEDOSPRODUTORES DE ALGODÃO (AMPA), ASSOCIAÇÃO DOS PRODUTORES DE SOJA E MILHO DE MATO GROSSO (APROSOJA-MT), EMPRESA BRASILEIRA DE PESQUISA AGROPECUÁRIA (EMBRAPA) (Org.). Desafios do Cerrado: como sustentar a expansão da produção com produtividade e competitividade. Cuiabá: Associação Matogrossense dos Produtores de Algodão, 2016. p.149-188.

REHAN, A.; FREED, S. Selection, mechanism, cross-resistance and stability of spinosad resistance in Spodoptera litura (Fabricius) (Lepidoptera: Noctuidae). Crop Protection, Guildford, v.56, p.1015, 2014. https://doi.org/10.1016/j.cropro.2013.10.013

SAKUMA, M. Probit analysis of preference data. Applied Entomology and Zoology, Tokyo, v.33, n.3, p.339-347, 1998. https://doi. org/10.1303/aez.33.339

SANG, S.; SHU, B.; YI, X.; LIU, J.; HU, M.; ZHONG, G. Crossresistance and baseline susceptibility of Spodoptera litura (Fabricius) (Lepidoptera: Noctuidae) to cyantraniliprole in the south of China. Pest Management Science, Sussex, v.72, n.5, p.922-928, 2015. https://doi.org/10.1002/ps.4068 
SANTOS, V.C.; DE SIQUEIRA, H.A.A.; DA SILVA, J.E.; DE FARIAS, M.J.D.C. Insecticide resistance in populations of the diamondback moth, Plutella xylostella (L.) (Lepidoptera: Plutellidae), from the state of Pernambuco, Brazil. Neotropical Entomology, Londrina, v.40, n.2, p.264-270, 2011 . https://dx.doi.org/10.1590/ S1519-566X2011000200017

SCOTT, J.G. Unraveling the mystery of spinosad resistance in insects. Journal of Pesticide Science, Sussex, v.33, n.3, p.221227, 2008. https://doi.org/10.1584/jpestics.R08-04

SHAD, S.A.; SAYYED, A.H.; SALEEM, M.A. Cross-resistance, mode of inheritance and stability of resistance to emamectin in Spodoptera litura (Lepidoptera: Noctuidae). Pest Management Science, Sussex, v.66, n.8, p.839-846, 2010. https://doi.org/10.1002/ps.1950

SOSA-GÓMEZ, D.R.; OMOTO, C. Resistência a inseticidas e outros agentes de controle em artrópodes associados à cultura da soja. In: HOFFMANN-CAMPO, C.B.; CORRÊA-FERREIRA, B.S.; MOSCARDI, F. (Eds.). Soja: Manejo integrado de insetos e outros artrópodes-praga, Brasília: Embrapa, 2012. p.673-723.

SPARKS, T.C.; DRIPPS, J.E.; WATSON, G.B.; PAROONAGIAN, D. Resistance and cross-resistance to the spinosyns- a review and analysis. Pesticide Biochemistry and Physiology, San Diego, v. 102, n. 1, p.1-10, 2012. https://doi.org/10.1016/j.pestbp.2011.11.004

SPECHT, A.; DE PAULA-MORAES, S.V.; SOSA-GÓMEZ, D.R. Host plants of Chrysodeixis includens (Walker) (Lepidoptera, Noctuidae, Plusiinae). Revista Brasileira de Entomologia, Curitiba, v.59, n.4, p.343-345, 2015. https://doi.org/10.1016/j.rbe.2015.09.002
STACKE, R.F.; GIACOMELLI, T.; BRONZATTO, E.S.; HALBERSTADT, A.S.; GARLET, C.G.; MURARO, D.S.; GUEDES, J.V.C.; BERNARDI, O. susceptibility of Brazilian populations of Chrysodeixis includens (Lepidoptera: Noctuidae) to selected insecticides. Journal of Economic Entomology, Lanhan, v.112, n.3, p.1378-1387, 2019. https://doi.org/10.1093/jee/tozO3 1

SUN, R.; LIU, C.; ZHANG, H.; WANG, Q. Benzoylurea chitin synthesis inhibitors. Journal of Agricultural and Food Chemistry, Easton, v.63, n.31, p.6847-6865, 2015. https://doi.org/10.1021/ acs.jafc. 5 b02 2460

TWINE, P.H.; REYNOLDS, H.T. Relative susceptibility and resistance of the tobacco budworm to methyl parathion and synthetic pyrethroids in southern California. Journal of Economic Entomology, Lanham, v.73, n.2, p.239-242, 1980. https://doi.org/10.1093/ jee/73.2.239

WANG, D.; QIU, X.; REN, X.; NIU, F.; WANG, K. Resistance selection and biochemical characterization of spinosad resistance in Helicoverpa armigera (Hubner) (Lepidoptera: Noctuidae). Pesticide Biochemistry and Physiology, San Diego, v.95, n.2, p.90-94, 2009. https://doi.org/10.1016/j. pestbp.2009.07.003

WANG, W.; MO, J.; CHENG, J.; ZHUNG, P.; TANG, Z. Selection and characterization of spinosad resistance in Spodoptera exigua (Hubner) (Lepidoptera: Noctuidae). Pesticide Biochemistry and Physiology. San Diego, v.84, n.3, p.180-187, 2006. https:// doi.org/10.1016/j.pestbp.2005.07.002 